\title{
Application of an Integrated Approach including Yagya Therapy for the Management of Acute Pulmonary Edema with Mild Cardiomegaly
}

\author{
Vandana Shrivastava1, Lalima Batham $^{1}$, Saurabh Mishra ${ }^{2, *}$, Alka Mishra ${ }^{1}$ \\ ${ }^{I}$ Department of Ayurveda and Holistic Health, Dev Sanskriti Vishwavidyalaya, Gayatrikunj- \\ Shantikunj, Haridwar, Uttarakhand, India \\ ${ }^{2}$ Dev Sanskriti Vishwavidyalaya, Gayatrikunj-Shantikunj, Haridwar, Uttarakhand, India
}

"Corresponding Author: Saurabh Mishra - Email: sau.dsvv@gmail.com

\section{Cite this research article as follows:}

Shrivastava V, Batham L, Mishra S, Mishra A. Application of an integrated approach including yagya therapy for the management of acute pulmonary edema with mild cardiomegaly. Ayurveda evam Samagra Swasthya Shodhamala. 2020;2(1):1. [cited date]. Available from: https://sites.google.com/dsvv.ac.in/shodhamala-dahh/asssm21/asssm211

\section{License information for readers:}

The original contents published in this research publication, which include research articles, case reports, etc., are published under the Creative Commons Attribution (CC BY 4.0) License. Anyone may reproduce, distribute, translate and create derivative works of this original content, subject to full attribution to the original research publication (Ayurveda evam Samagra Swasthya Shodhamala) and authors. The full terms of this license may be seen at https://creativecommons.org/licenses/by/4.0/

\section{Published by:}

Department of Ayurveda and Holistic Health

Dev Sanskriti Vishwavidyalaya

Gayatrikunj-Shantikunj, Haridwar - 249411

Uttarakhand, India

Email:dahh@dsvv.ac.in

Mobile: +91 9258360953, +91 8954890390

Website: http://www.dsvv.ac.in/dahh

Published online: 25 February 2020 


\begin{abstract}
Background: A case report about a female patient has been presented here, who was suffering from multiple complaints including severe breathlessness, low grade fever, node in the chest, sleeplessness, etc., and whose diagnostic tests indicated acute pulmonary edema and mild cardiomegaly. Ever since the occurrence of low grade fever and breathlessness, the patient had been on allopathic medication. It was considered to be a possible case of Sarcoidosis. Since about four and a half months, the patient had been on a tapering dose of steroids, and these were recommended to be continued for another two months. The persisting symptoms of low grade fever, breathlessness, and other associated ailments had significantly degraded the quality of life of the patient.

Methodology: The patient was prescribed an integrated approach including Yagya Therapy (using an appropriate herbal formulation - havan samagri), and some other Ayurvedic treatments like decoction of medicinal herbs, Ayurvedic medicines, dietary recommendations, etc., which had to be taken alongside the already continuing allopathic treatment (which continued for about 2.5 months).
\end{abstract}

Results: According to a feedback collected from the patient about 2 years after starting the integrated approach including Yagya Therapy, the complaints of low grade fever, sleeplessness, body pain, loss of appetite, constipation and weakness were completely resolved; the complaint of breathlessness was almost completely resolved; the node in the chest had disappeared about seven months after starting the integrated approach (including Yagya Therapy); X-ray Chest (done about four months after starting the integrated approach, and also after about two years), and CT scan (CECT Chest and Abdomen) (done about seven months after starting the integrated approach) indicated normal condition. After starting the integrated approach (including Yagya Therapy), within about 2 to 3 months, the patient had started feeling improvement in her condition - now the patient was feeling completely normal, and expressed willingness to continue with the integrated approach (including Yagya Therapy)

Conclusion: The integrated approach including Yagya Therapy showed encouraging results with regards to the treatment of the present disease condition.

Keywords: Pulmonary Edema, Cardiomegaly, Yagya Therapy, Yagyopathy, Ayurveda, Pulmonary Inhalation, Herbal Medicine 


\section{Introduction}

This case report is about a female patient (age 33 years) who was suffering from multiple complaints including:

- low grade fever $\left(100^{\circ}\right.$ to $\left.101^{0} \mathrm{~F}\right)$ (since about 10 months - earlier it used to be there all the time, but after taking medication it became intermittent about 5 months back)

- breathlessness (since about 10 months - extreme when doing strenuous physical activity)

- presence of chest node (gradually increasing in size)

- hair fall (since about 2 months)

- sleeplessness

- loss of appetite

- body pain

- constipation

- weakness

- $\quad$ stress and mild depression

The patient had past history of:

- dust allergy (since childhood) (had cough and cold for about 6 months, after which the symptoms of low grade fever and breathlessness appeared suddenly)

- left facial palsy (about 5 months back)

- bulbar palsy (about 6 months back)

There was no past history of diabetes mellitus, hypertension, asthma, hypothyroidism.

Past diagnostic tests gave the following information:

- X-ray Chest PA View (done a few days ago) indicated mild cardiomegaly with acute pulmonary edema

- Pulmonary Function Test (done about 2 months back) indicated mild restrictive abnormality

- X-ray Chest AP View (done about 5 months back) - it was mentioned that the left hilum appears prominent, possibly enlarged nodes

- CT scan (HRCT of lungs and non-ionic IV contrast study of thorax) (done about 5 months back) indicated multiple superior mediastinal and subcarinal nodes, largest subcarinal $18 \mathrm{~mm}$ having faint peripheral calcification without necrosis - it was mentioned that findings non-specific but likely due to granulomatous disorder

- MRI Brain (Plain + Contrast) (done about 5 months back) indicated diffuse thickening and enhancement of pituitary stalk, with convexity of superior surface of pituitary the possibility of ?sarcoidosis, ?lymphocytic hypophysitis was expressed in the report

- CT scan (Chest: homogeneous mediastinal LNs) (done about 4 months back) - it was mentioned that enlarged lymph nodes identified in the subcarinal LN station; size significantly regressed as compared to the CT scan done earlier (given above, i.e. about 5 months back)

- Transbronchial Lung Biopsy (done about 4 months back) - it was mentioned that it shows tiny fragment of collapsed lung parenchyma, no granulomas are seen 
- Endobronchial Lung Biopsy (done about 4 months back) - it was mentioned that it shows tiny mucosal fragment with minimal chronic inflammation, no granulomas seen in section examined

Ever since the occurrence of low grade fever and breathlessness, the patient had been on allopathic medication. It was considered to be a possible case of Sarcoidosis. Since about four and a half months, the patient had been on a tapering dose of steroids, and these were recommended to be continued for another two months.

Based on the above mentioned medical history, information from diagnostic tests, and further discussion with the doctor, the current diagnosis for the patient included mild cardiomegaly, with acute pulmonary edema, and a possible case of ?Sarcoidosis. The persisting symptoms of low grade fever, breathlessness, and other associated ailments had significantly degraded the quality of life of the patient. Looking at the beneficial effects of Yagya Therapy in the treatment of various diseases [1-13] (including pulmonary diseases like pulmonary tuberculosis [2-4]), and in improving the quality of life of the patients, an integrated approach including Yagya Therapy was prescribed for the patient, which had to be taken alongside the already continuing allopathic treatment.

\section{Methodology}

An integrated approach including Yagya Therapy (using an appropriate herbal formulation), and some other Ayurvedic treatments like decoction of medicinal herbs, Ayurvedic medicines, dietary restrictions, lifestyle modifications, etc., was prescribed for the patient, with the understanding that she was an Out Patient Section patient, and would be taking these treatments at her home.

Informed consent was obtained from the patient's guardian before the start of the therapy.

The prescribed therapeutic interventions were as follows:

\subsection{Yagya Therapy with havan samagri (herbal mixture) for Asthma (Dama) and havan samagri for Hridaya Roga (Heart disease)}

Patient was advised to follow the standard protocol of Yagya at home. The standard protocol of Yagya is given in references [1,3,4]; more details about the various procedures can be found in references $[11,14,15]$. A brief description with regards to the present study is as follows:

Department of Ayurveda and Holistic Health (DAHH), Dev Sanskriti Vishwavidyalaya, Haridwar prescribed two havan samagri to the patient - one for Asthma (Dama), and the other for Hridaya Roga (Heart disease). The composition of these havan samagri is based on the formulations for the same given in reference [4]. No metal was used in the herbal preparation. All ingredients were well identified by taxonomist [16-18], were non-toxic, and could be useful in the treatment of the patient's complaints. Along with these two disease specific havan samagri, the patient was also prescribed a common purpose immunity-boosting havan samagri, whose composition was based on the formulation for the same given in references $[3,4]$. Havan samagri for Asthma (Dama), Hridaya Roga (Heart disease), and common 
purpose havan samagri had to be mixed in $1.5: 1.5: 1$ ratio, i.e. $15 \mathrm{gm}, 15 \mathrm{gm}$ and $10 \mathrm{gm}$, respectively; $30 \mathrm{gm}$ cow ghee had to be added to this herbal mixture, to get the final herbal preparation with which oblations had to be made in the Yagya.

The pre-procedures for Yagya included doing Shatkarma for both internal and external purification (Pavitrikaran, Achaman, Shikhavandan, Nyas - i.e. spiritual practices for purification), Prithvi Pujan (prayers to Mother Earth), Chandan-dharan (applying sandalwood paste or roli - auspicious red powder on forehead), Guru-avahan (invoking the spiritual guide). This was followed by making 24 oblations of the herbal preparation (described above) in the Yagya fire, along with the chanting of Gayatri Mantra. Next, the patient had to do pranayama and deep breathing, while sitting near the Yagya.

Yagya had to be done two times daily, i.e. at the time of Sunrise and Sunset. The patient was advised to do Yagya Therapy for 3 months.

\subsection{Drinking decoction of herbal mixture for Asthma (Dama) and Hridaya Roga (heart disease)}

Patient was advised to drink the decoction of the herbal mixture for Asthma (Dama) and Hridaya Roga (heart disease), wherein 10 to $15 \mathrm{gm}$ of each herbal mixture had to be mixed in 4.5 cups of water (about $100 \mathrm{ml}$ per cup); kept overnight; boiled the next morning till 1.5 cups (about $150 \mathrm{ml}$ ) of water remained; this was to be divided in two equal parts, and taken empty stomach two times during the day.

\subsection{Ayurvedic medicines}

- Kanchanar Guggul - 2 tablets had to be taken twice daily with lukewarm water

- Amrita Guggul - 2 tablets had to be taken twice daily with lukewarm water

- Trikatu Churna

- Lavan Bhaskar Churna

\subsection{Dietary advice}

- It was advised to take food items like alsi (linseed - Linum usitatissimum), methi (fenugreek - Trigonella foenum-graecum), ajwain (Carum copticum), turmeric (Curcuma longa), and dry fruits such as walnut, anjeer (fig), khajoor (dates)

- Take satvik (pious, natural and healthy) food; take dalchini (cinnamon), saindhav lavan (rock salt)

\section{Results}

In the present case study, the outcomes were assessed in a qualitative (subjective) manner based on the diagnostic reports, and the patient's experiential feedback.

Once the integrated approach was advised for the patient, she continued with the same at her home. A feedback about the condition of the patient was collected about 2 years after starting the integrated approach including Yagya Therapy (i.e. during one of the times when her medicinal havan samagri had finished, and she wanted to get the same again from DAHH); 
the details of the same are as follows:

- The patient had been doing Yagya regularly, every morning, i.e. one time during the day, since about 2 years (i.e. ever since Yagya Therapy was prescribed)

- The duration of Yagya was about 20-30 minutes, and after the completion of Yagya, patient stayed in that room for about 10-15 minutes

- After the completion of Yagya, patient did Pranayama for about 10 minutes

- The patient had been drinking the prescribed decoction twice a day

- As described in the Introduction above, the patient had been taking allopathic medication earlier; she simultaneously continued to take the same during about first 2.5 months of starting the integrated approach (including Yagya Therapy)

The details of the relief experienced by the patient are as follows:

- Earlier the patient used to have low grade fever; now this complaint was completely resolved, and the patient felt normal

- Earlier the patient used to experience severe breathlessness; now this complaint was almost completely resolved

- Earlier the patient had a node in the chest, whose size was gradually increasing; now this complaint was completely resolved; the chest node had disappeared about seven months after starting the integrated approach (including Yagya Therapy)

- Earlier the patient used to experience severe sleeplessness; now this complaint was completely resolved

- Earlier the patient used to experience considerable body pain; now this complaint was completely resolved

- After starting the integrated approach (including Yagya Therapy), within about 2 to 3 months, the patient started feeling improvement in her condition - now the patient was feeling completely normal, and expressed willingness to continue with the integrated approach (including Yagya Therapy)

The results indicated by diagnostic tests, conducted after starting the integrated approach (including Yagya Therapy), are as follows:

- X-ray Chest PA View (done about four months after starting the integrated approach) indicated normal condition

- X-ray Chest PA View (done about two years after starting the integrated approach) indicated normal conditon

- CT scan (CECT Chest and Abdomen) (done about seven months after starting the integrated approach) indicated no significantly enlarged mediastinal lymph nodes, and normal lung parenchyma

For some questions in the feedback form, the response was collected on a five point scale, with the increase in the reported percentage value indicating the increase in severity of the complaint of the patient; this response was collected with regards to the condition of the patient, both before and after taking the integrated approach (including Yagya Therapy). This scale started from $0 \%$, i.e. 'No problem', up to a maximum of $100 \%$, i.e. 'Very Severe', with intermediate values of $25 \%, 50 \%$ and $75 \%$. The responses collected in this regard are listed in Table 1. 
It can be seen from Table 1 that the patient experienced notable relief with regards to her various complaints including breathlessness, body pain, sleeplessness, loss of appetite, constipation and weakness.

Thus, it can be seen that the integrated approach (including Yagya Therapy) provided relief in the primary complaints of the patient, and also made a notable contribution in improving her quality of life.

Table 1: Feedback about the patient's condition, before and after taking the integrated approach (including Yagya Therapy)

\begin{tabular}{|l|c|c|}
\hline Questions related to patient's experience & $\begin{array}{c}\text { \% Severity } \\
\text { Before }\end{array}$ & $\begin{array}{c}\% \text { Severity } \\
\text { After }\end{array}$ \\
\hline Do you feel pain in the body? & $75 \%$ & $0 \%$ \\
\hline Do you feel difficulty in sleeping? & $100 \%$ & $0 \%$ \\
\hline Do you feel loss in appetite? & $75 \%$ & $0 \%$ \\
\hline Do you keep vomiting? & $25 \%$ & $0 \%$ \\
\hline Do you have constipation? & $75 \%$ & $0 \%$ \\
\hline Do you feel weakness? & $50 \%$ & $0 \%$ \\
\hline Do you feel difficulty in breathing? & $100 \%$ & $25 \%$ \\
\hline Do you feel unhappiness/depression? & $25 \%$ & $25 \%$ \\
\hline Do you feel stress? & $50 \%$ & $25 \%$ \\
\hline
\end{tabular}

\section{Discussion}

The present study illustrates the potential of an integrated approach (including Yagya Therapy) for the treatment of a patient suffering from multiple complaints including severe breathlessness, low grade fever, node in the chest, sleeplessness, etc., and the diagnostic tests indicating acute pulmonary edema and mild cardiomegaly.

According to Ayurveda, a healthy human body is supposed to have a relatively stable equilibrium (congenial homeostasis) of Dosha (psycho-biological rhythm - Vata, Pitta, Kapha), Dhatu (body tissues and their nourishing elements) and Mala (excreta) [16,17]; Acharya Sushruta defines health as an equilibrium of Dosha (psycho-biological rhythm), Agni (digestion and metabolism), Dhatu (body tissues), Malakriya (excretory function), as well as the well being of soul, senses and mind [16,17]. Imbalance in this equilibrium leads to disease, and the aim of the therapy is to restore this balance [17-19].

As per Ayurvedic texts, one of the primary reasons for the occurrence of any kind of Shwasa Roga (respiratory disease) is Srotorodha (obstruction) of the Pranavaha Srotas (microchannel); this Srotorodha is mainly caused by the vitiation of the Kapha and Vata Doshas [17,19-22]. The occurrence of breathlessness after exertion is called Shrama Shwasa, which is a predominant symptom of vitiated Pranavaha Srotas; the vitiation of Pranavaha Srotas 
causes morbidity in the heart leading to Hridrog (heart disease) $[17,19,20,23]$. Hence, the medicinal herbs and therapies that balance the respective Doshas, and provide nourishment and strength to the affected body tissues, were used in the Ayurvedic treatment of the disease symptoms observed in the present study.

Yagya is an ancient Indian therapeutic procedure, which nurtures nature's ecological balance, resulting in all-round well-being of an individual, as well as the entire cosmos [1,5,10-12]. With regards to the subtle and emotional aspects of Yagya affecting a person, the feeling of 'giving' is inherently associated with Yagya, i.e. feeling, understanding and acknowledging that a person is an inseparable constituent of the nature and society, has immensely benefited from these thoroughout life, and hence it is the duty of the person to give a part of one's compassion, feelings, endeavors, resources, etc. for the betterment of the nature and society; this sense of responsibility significantly contributes to the positive restructuring of the psyche of the person, leading to an all round physical, mental and emotional well being; also, the nature reciprocates these feelings, which further contributes to the overall betterment of the person $[3,4,10-12]$.

In the process of Yagya, coarse powder (havan samagri) made up of dry plant-medicines, as well as selected nutritious and aromatic substances, undergoes transformation into vapor phase; these phytomedicines spread along with the volatile substances and gases, released by the slow and controlled combustion process in Yagya fire [1-5,10-12]. In addition, frequent oral and nasal inhalation of phytomedicines in medicinal-fumes, generated in Yagya, takes place because of the rhythmic deep breathing exercise (pranayama) and chanting of certain Vedic hymns (Mantras) by the subjects (patients) throughout the duration of the Yagya, which contributes to the efficient pulmonary administration of phytomedicines, and the desired therapeutic benefit $[1-5,10-12]$.

Administration of multi-herbs through oral administration can have limitations such as firstpass metabolism [9]. In case of nasal drug administration, absorption takes place from the nasal cavity into the systemic circulation, and the first-pass metabolism is avoided [9,24]. Furthermore, the blood-brain barrier is also avoided, and the medicinal drugs can be transported directly from the nasal cavity into the brain [24]. Thus, nasal administration of herbal medicines through Yagya Therapy may be considered as an important aspect with regards to the therapeutic advantage observed in the present study.

The process of pulmonary drug administration of plant medicines during Yagya is similar to that during Nasya, which is a common purificatory therapeutic procedure in the Panchakarma Therapy of Ayurveda, wherein herbal medicines are administered through the nasal route, in different forms including oil, powder and vapors [19]. Nasya primarily affects the urdhvajatrugata pradesha (supra-clavicular region) $[25,26]$. According to Acharya Vagbhatta, nose is one of the most convenient routes to convey medicinal effects to the cranial cavity [25]. According to Acharya Charaka, nasya drug usually acts through absorption by the Shringataka marma (a vital spot in the head region situated at the site of the union of the nerves, supplying to the nose, ears, eyes, and tongue); after absorption, the medicine acts on the diseases of the respiratory system, shoulder, neck, etc., and the vitiated Doshas are expelled from the head region [25]. Thus, the administered medicine moves up to the Shringataka marma, spreads all over the head, channels of eyes, ears, nose and throat, and removes vitiated Doshas from there [25,26]. 
Based on the disease condition in the present study, the Yagya Therapy prescribed to the patient included havan samagri (mixture of medicinal herbs) for Dama (Asthma) and havan samagri for Hridaya Roga (heart disease). The havan samagri contained herbs, which were chosen based on careful review of Ayurvedic pharmacology, modern pharmacology, and scriptural indications. The beneficial properties of some of the herbs with regards to the treatment of present disease condition, are as follows:

\section{Havan Samagri for Dama (Asthma)}

- Tulasi (Ocimum Sanctum), Vasa (Adhatoda vasica), Kantakari (Solanum xanthocarpum) and Haldi (Curcuma longa) have Kapha pacifying property; Methi (Trigonellafoenumgraecum) and Pippali (Piper longum) have Vata pacifying property [27-29].

- Nagarmotha (Cyperus rotundus), Chirayata (Swertia Chirayita) and Pippali (Piper longum) have Deepan Pachan properties [27-29]; Deepan Pachan drugs are administered for enhancing the digestive fire [30,31] and digestion of the ama dosha (undigested toxins of the body that are responsible for the blockage of microchannels).

- Methi (Trigonellafoenumgraecum), Kakadashringi (Pistacia integerrima) and Ajwain (Carum copticum) have Balya property, i.e. they provide strength to the body tissues [27-29].

- Chirayata (Swertia Chirayita) and Indra Jau (Holarrhena antidysenterica) provide relief in fever [27].

- Kakadashringi (Pistacia integerrima) provides relief in the swelling of the shwasnalika (wind pipe) [27].

\section{Havan Samagri for Hridaya Roga (heart disease)}

- Sonth (Zingiber Officinale) and Rasna (Pluchea lanceolata) have Vata and Kapha pacifying properties; Arjun Chhal (Terminalia arjuna) has Kapha and Pitta pacifying properties; Daruhaldi (Berberis aristata DC) has Pitta pacifying property [27-29].

- Arjun Chhal (Terminalia arjuna) provides relief in hridaya vikar (heart disorders) [27].

- Jatamansi (Nardostachys Jatamansi) has hridaya-balya property, i.e. provides strength to the heart [27].

- Rasna (Pluchea lanceolata) has shwashar property, i.e. it provides relief in breathlessness [27].

- Shalaparni (Desmodium gangeticum) provides relief in fuffusshotha, i.e. the pulmonary edema [27].

- Daruhaldi (Berberis aristata DC) provides relief in fever [27].

- Punarnava (Boerhavia diffusa) provides relief in swelling [27].

- Kutaki (Picrorhiza kurroa) has Deepan Pachan properties [27-29]; Deepan Pachan drugs are administered for enhancing the digestive fire [30,31] and digestion of the ama dosha (undigested toxins of the body that are responsible for the blockage of micro-channels).

- Daruhaldi (Berberis aristata DC) and Brahmi (Centella asiatica) have Balya and Rasayan properties, i.e. provide strength and rejuvenation [27-29]. 
Thus, the ingredients of the two havan samagri have properties of pacifying the vitiated Doshas, providing strength and rejuvenation, and providing relief in the various disease symptoms; their vapors help in the treatment of the disease condition observed in the present study.

In Yagya Therapy, ghee (clarified butter) is essentially added to havan samagri. According to Ayurveda, ghee enhances the digestive fire (agni), and nourishes ojas (the subtle essence of the body tissues - Dhatus) [32]. It helps in memory enhancement and strengthening of the nervous system [32]. It also has Vata and Pitta pacifying properties [32]. Because of its yogavahi guna, it has the property that without losing its own qualities, it can incorporate the qualities of the herbal medicines added to it; furthermore, it transports the same to deeper body tissues through its lipophilic action [32,33]. According to modern research findings, lipid nanoparticles have been shown to enhance drug delivery through the nasal route [24].

The Vedic hymns (Mantras) chanted during Yagya are intense spiritual prayers to the Almighty for the well being of both the self, as well as the entire cosmos [1,3-5,10-12]. During the chanting of these Mantras, the participants are supposed to continuously meditate on their meaning; thus, this chanting creates a continuous process of meditation and contemplation, which contributes to the positive restructuring of the psyche of the participants [1,3-5,10-12]. The Mantras have a unique combination of syllables and words, which when chanted in a rhythmic manner, lead to the creation of distinct and powerful sound waves that contribute to the desired therapeutic benefit on the physical, mental and emotional level [3,4,10-12]. The chanting of Gayatri Mantra causes beneficial effects with regards to various physical and mental conditions like attention, concentration, etc. [12,34-39].

During Yagya, the patient has to sit near the Yagya fire for a specified amount of time; this way, the patient experiences the bright light and heat of the fire [1,3-5,10-12], which have their own therapeutic advantages such as relief from depression caused by bright light [40,41], sudation (swedan) caused by heat, etc.; according to Ayurveda, swedan (sudation) has actions like Stambhaghna (relieves stiffness), Sweda-karak (creates perspiration), and Gauravaghna (cures heaviness) [42].

Thus, Yagya Therapy (Yagyopathy) presents a multi-modal approach for the treatment of diseases.

Yagya has also been found useful in purifying the indoor environment. Saxena (2006) [43] (did experiments in collaboration with Central Pollution Control Board, Delhi, India) studied the effect of yagya on air microflora, bacteria and pathogens; in indoor experiments, she found significant reduction in pathogens, bacteria and microflora, even 2-3 days after yagya. This environment purifying effect of Yagya must also have contributed to the creation of a healthy environment in patient's home, and the observation of the encouraging results seen in the present study.

Patient took the decoction of prescribed herbal mixtures twice daily. As described above, the herbs in the prescribed herbal mixtures have properties that pacify the vitiated Doshas, as well as provide nourishment, strength and rejuvenation. Thus, the decoction must have provided these therapeutic benefits as well.

Patient was advised to do Pranayama and deep breathing while sitting near the Yagya. The 
patient did Pranayama for about 10 minutes daily after the completion of the Yagya; this must have resulted in a greater intake of the medicinal fumes generated during Yagya, and hence an enhancement in the therapeutic benefits. Furthermore, Pranayama is known to have several other therapeutic benefits that would have contributed to the beneficial results observed in the present study. Anulom Vilom Pranayama can cause enhancement of the ventilation and oxygenation of the paranasal sinuses [44]. Pranayama / Alternate Nostril Breathing significantly influences the parasympathetic nervous system [45]. Slow yogic breathing technique produces beneficial effect on cardiovascular and autonomic variables [46]. Slow Pranayama improves pulmonary function, and results in relaxed state of mind, better concentration, and improved lung ventilation [47].

The Ayurvedic medicines prescribed to the patient included - Kanchanar Guggul that has properties of pacifying the Vata and Kapha Doshas, dissolving a cyst, and anti-inflammatory action [48]; and, Amrita Guggul that has Vata and Kapha pacifying, Rasayana (rejuvenation), and immunity boosting properties [49].

The dietary recommendations included taking food items that are known to be beneficial for the respiratory system and the heart, as well as provide nourishment and boost the immunity.

It is noteworthy that the present study was done in OPD (Out-Patient Department) setting, wherein the therapy was prescribed for the patient, and she was required to do Yagya and follow other therapeutic procedures at her home. Such a setting has obvious limitations with regards to following the prescribed procedure and dietary recommendations, as well as taking medications, etc.; however, the patient still reported notable benefit. Thus, the present study shows encouraging result with regards to the effectiveness of integrated approach including Yagya Therapy in the treatment of the present disease condition. There is definitely a need for further in-depth quantitative study to establish the mode of operation of this integrated approach in the light of modern scientific understanding.

\section{Conclusion}

A case report about a female patient has been presented here, who was suffering from multiple complaints including severe breathlessness, low grade fever, node in the chest, sleeplessness, etc., and whose diagnostic tests indicated acute pulmonary edema and mild cardiomegaly; the persisting disease symptoms had significantly degraded the quality of life of the patient. The patient was prescribed an integrated approach including Yagya Therapy (using an appropriate herbal formulation - havan samagri), and some other Ayurvedic treatments like decoction of medicinal herbs, Ayurvedic medicines, dietary recommendations, etc., which had to be taken alongside the already continuing allopathic treatment taken by the patient (which continued for about 2.5 months after starting the integrated approach including Yagya Therapy).

According to a feedback collected from the patient about 2 years after starting the integrated approach including Yagya Therapy, the complaints of low grade fever, sleeplessness, body pain, loss of appetite, constipation and weakness were completely resolved; the complaint of breathlessness was almost completely resolved; the node in the chest had disappeared about seven months after starting the integrated approach (including Yagya Therapy); X-ray Chest (done about four months after starting the integrated approach, and also after about two 
years), and CT scan (CECT Chest and Abdomen) (done about seven months after starting the integrated approach) indicated normal condition. After starting the integrated approach (including Yagya Therapy), within about 2 to 3 months, the patient had started feeling improvement in her condition - now the patient was feeling completely normal, and expressed willingness to continue with the integrated approach (including Yagya Therapy).

Thus, the present study shows encouraging result with regards to the effectiveness of integrated approach including Yagya Therapy in the treatment of the present disease condition.

\section{Acknowledgements}

Authors would like to acknowledge the subtle guidance of their spiritual guide, Revered Pandit Shriram Sharma Acharya (http://www.awgp.org/about_us/patron_founder), who founded the organization - All World Gayatri Pariwar. The authors thank the faculty and staff of the Department of Ayurveda and Holistic Health, Dev Sanskriti Vishwavidyalaya, Haridwar for their support in conducting this study.

\section{Compliance with ethical standards}

Informed consent was obtained from the patient's guardian before the start of the therapy.

\section{Conflict of interest}

The authors declare that they have no conflict of interest.

\section{References}

1. Shrivastava V, Batham L, Mishra A. Yagyopathy (yagya therapy) for various diseases - an overview. Ayurveda evam Samagra Swasthya Shodhamala. 2019; 1(1): 2. [cited 5 Dec 2019].

Available from: https://sites.google.com/dsvv.ac.in/shodhamala-dahh/asssm11/asssm112

2. Raghuvanshi M. Some investigations into the chemical and pharmaceutical aspects of yagyopathy: studies in pulmonary tuberculosis. Thesis for the degree of Doctor of Philosophy (Ph.D.) in Oriental Studies. Haridwar, Uttarakhand, India: Dev Sanskriti Vishwavidyalaya (http://www.dsvv.ac.in/); 2006.

3. Pandya P. Applied science of yagya for health and environment. Haridwar, Uttarakhand, India: Shri Vedmata Gayatri Trust (TMD), Shantikunj; 2011. (http://literature.awgp.org/book/Applied_Science_of_Yagya_for_Health_and_Environment/v1)

4. Brahmavarchas. Yagya chikitsa (Hindi). Haridwar, Uttarakhand, India: Shri Vedmata Gayatri Trust (TMD), Shantikunj; 2016.

5. Mishra A, Batham L, Verma S, Mishra S, Shrivastava V. Management of epileptic seizures through an integrated approach including yagya therapy. Interdisciplinary Journal of Yagya Research. 2019; 2(1): 52-64.

(http://ijyr.dsvv.ac.in/index.php/ijyr/article/view/24)

6. Batham L, Choudhary L, Mishra A, Shrivastava V. Yagya therapy for epileptic seizures: a case study. Interdisciplinary Journal of Yagya Research. 2018; 1(2): 37-42. (http://ijyr.dsvv.ac.in/index.php/ijyr/article/view/14) 
7. Verma S, Kumar P, Mishra A, Shrivastava V. Yagya therapy for sub-clinical hypothyroidism: a case study. Interdisciplinary Journal of Yagya Research. 2018; 1(2): 31-36.

(http://ijyr.dsvv.ac.in/index.php/ijyr/article/view/13)

8. Shrivastava V, Batham L, Mishra S, Mishra A. Management of symptoms associated with obsessive-compulsive disorder (ocd) and polycystic ovarian disease (pcod) through an integrated approach including yagya therapy. Interdisciplinary Journal of Yagya Research. 2019; 2(1): 39-51.

(http://ijyr.dsvv.ac.in/index.php/ijyr/article/view/28)

9. Mishra A, Batham L, Shrivastava V. Yagya therapy as supportive care in cancer patients improved quality of life: case studies. Interdisciplinary Journal of Yagya Research. 2018; 1(1): 26-33.

(http://ijyr.dsvv.ac.in/index.php/ijyr/article/view/3)

10. Joshi RR. The integrated science of yagya. Mathura, Uttar Pradesh, India: Yug Nirman Yojana Vistar Trust, Gayatri Tapobhumi; 2011. (http://literature.awgp.org/book/the_integrated_science_of_yagna/v1)

11. Brahmavarchas. Yagya ka gyan-vigyan (Hindi). Pandit Shriram Sharma Acharya samagra vangamaya. volume 25. Mathura, Uttar Pradesh, India: Akhand Jyoti Sansthan; 1998.

12. Brahmavarchas. Yagya - ek samagra upachar prakriya (Hindi). Pandit Shriram Sharma Acharya samagra vangamaya. volume 26. revised ed. Mathura, Uttar Pradesh, India: Akhand Jyoti Sansthan; 2012.

13. Shrivastava V. Yagyopathy - ek adhyatmik upachar kram (Hindi). Haridwar, Uttarakhand, India: Dev Sanskriti Vishwavidyalaya; 2019.

14. Sharma S. Saral aur sarvopayogi Gayatri havan-vidhi (Hindi). Mathura, Uttar Pradesh, India: Yug Nirman Yojana Vistar Trust, Gayatri Tapobhumi; 2012.

(http://literature.awgp.org/book/procedure_of_gayatri_yagya/v8)

15. Sharma S. Form and spirit of vedic ritual worship: procedure of yagya. translation by Poddar K, Shambhudass. Mathura, Uttar Pradesh, India: Yug Nirman Yojana Vistar Trust, Gayatri Tapobhumi; 2011.

(http://literature.awgp.org/book/procedure_of_gayatri_yagya/v1)

16. Kadlimatti SM, Maheshwari KS, Chandola HM. Critical analysis of the concept of asthi kshaya vis-a-vis osteoporosis. Ayu. 2009; 30(4): 447-458.

(http://www.ayujournal.org/temp/Ayu304447-2819005_074950.pdf)

17. Murthy KRS. Susruta samhita - Vol. I, II, III. Varanasi, Uttar Pradesh, India: Chaukhambha Orientalia; 2008.

18. Nagral KS. Ayurved for modern medical practitioners. Delhi, India: Chaukhamba Sanskrit Pratishthan; 2008.

19. Sharma PV. Charaka-samhita (text with English translation). volume I, II. Varanasi, Uttar Pradesh, India: Chaukhambha Orientalia; 2008.

20. Shastri S. Madhava nidanam of sri madhavakara (Hindi). part-1. 30th ed. Varanasi, Uttar Pradesh, India: Chaukhamba Sanskrit Sansthan; 2000.

21. Ram J, Baghel MS. Clinical efficacy of vyaghriharitaki avaleha in the management of chronic bronchitis. Ayu. 2015; 36(1): 50-55.

(https://www.ncbi.nlm.nih.gov/pmc/articles/PMC4687240/)

22. Yadav SS, Galib, Patgiri B, Prajapati PK. Clinical efficacy of two different samples of shirishavaleha in tamaka shwasa (bronchial asthma). Ayu. 2012; 33(2): 255-260.

(https://www.ncbi.nlm.nih.gov/pmc/articles/PMC3611652/) 
23. Baikampady SV. Dyspnea on exertion in patients of heart failure as a consequence of obesity: an observational study. Ayu. 2013; 34(2): 160-166.

(https://www.ncbi.nlm.nih.gov/pmc/articles/PMC3821244/)

24. Fatouh AM, Elshafeey AH, Abdelbary A. Intranasal agomelatine solid lipid nanoparticles to enhance brain delivery: formulation, optimization and in vivo pharmacokinetics. Drug Design, Development and Therapy. 2017; 11: 1815-1825. (https://www.ncbi.nlm.nih.gov/pmc/articles/PMC5484509/)

25. Das B, Ganesh RM, Mishra PK, Bhuyan G. A study on apabahuka (frozen shoulder) and its management by laghumasha taila nasya. Ayu. 2010; 31(4): 488-494.

(https://www.ncbi.nlm.nih.gov/pmc/articles/PMC3202264/)

26. Radhika C, Kumar GV, Mihirjan K. A randomized controlled clinical trial to assess the efficacy of nasya in reducing the signs and symptoms of cervical spondylosis. Ayu. 2012; 33(1): 73-77.

(https://www.ncbi.nlm.nih.gov/pmc/articles/PMC3456869/)

27. Misra B, Vaisya R. Bhavaprakasa of shri bhava misra (including bhavaprakasa nighantu portion) - edited with the 'vidyotini' hindi commentary, notes and appendix - first part. Varanasi, Uttar Pradesh, India: Chaukhambha Sanskrit Bhawan; 2013.

28. Sharma PV. Dravyaguna vijnana - volume II (vegetable drugs) (hindi). Varanasi, Uttar Pradesh, India: Chaukhambha Bharati Academy; 2001.

29. Sastry JLN. Illustrated dravyaguna vijnana - volume II (study of the essential medicinal plants in Ayurveda). Varanasi, Uttar Pradesh, India: Chaukhambha Orientalia; 2017.

30. Dudhamal TS, Gupta SK, Bhuyan C, Singh K. The role of apamarga kshara in the treatment of arsha. Ayu. 2010; 31(2): 232-235.

(https://www.ncbi.nlm.nih.gov/pmc/articles/PMC3215370/)

31. Lekurwale PS, Pandey K, Yadaiah P. Management of amavata with 'amrita ghrita': a clinical study. Ayu. 2010; 31(4): 430-435.

(https://www.ncbi.nlm.nih.gov/pmc/articles/PMC3202259/)

32. Sharma H, Zhang X, Dwivedi C. The effect of ghee (clarified butter) on serum lipid levels and microsomal lipid peroxidation. Ayu. 2010; 31(2): 134-140.

(https://www.ncbi.nlm.nih.gov/pmc/articles/PMC3215354/)

33. Joseph CR, Ilanchezhian R. Experimental evaluation of hingusauvarchaladi ghrita and saptavartita hingusauvarchaladi ghrita with special reference to their anticonvulsant activity. Ayu. 2010; 31(4): 500-503.

(https://www.ncbi.nlm.nih.gov/pmc/articles/PMC3202270/)

34. Brahmavarchas. Shabda brahma - nad brahma (Hindi). Pandit Shriram Sharma Acharya samagra vangamaya. volume 19. 2nd ed. Mathura, Uttar Pradesh, India: Akhand Jyoti Sansthan; 2012.

35. Sharma S. Eternity of sound and the science of mantras. Mathura, Uttar Pradesh, India: Yug Nirman Yojana Vistar Trust, Gayatri Tapobhumi; 2012.

(http://literature.awgp.org/book/Eternity_of_Sound_and_The_Science_of_Mantras/v1)

36. Malhotra V, Goel N, Dhar U, Garg R, Tripathi Y. Comparison of mind control techniques: an assessment of reaction times. Bangladesh Journal of Medical Science. 2016; 15(4): 596-600.

(https://www.banglajol.info/index.php/BJMS/article/view/30718)

37. Pradhan B, Derle SG. Comparison of effect of gayatri mantra and poem chanting on digit letter substitution task. Ancient Science of Life. 2012; 32(2): 89-92.

(https://www.ncbi.nlm.nih.gov/pmc/articles/PMC3807963/) 
38. Sharma S. Super science of gayatri. revised ed. translation by Pandya SN, Shambhudas. Mathura, Uttar Pradesh, India: Yug Nirman Yojana Vistar Trust, Gayatri Tapobhumi; 2010 .

(http://literature.awgp.org/book/Super_Science_of_Gayatri/v1.1)

39. Sharma S. Gayatri mahavigyan - sanyukta sanskaran (Hindi). revised ed. Mathura, Uttar Pradesh, India: Yug Nirman Yojana Vistar Trust, Gayatri Tapobhumi; 2010. (http://literature.awgp.org/book/Super_Science_of_Gayatri/v2)

40. $\mathrm{Li} \mathrm{X}, \mathrm{Li} \mathrm{X}$. The antidepressant effect of light therapy from retinal projections. Neuroscience Bulletin. 2018; 34(2): 359-368.

(https://www.ncbi.nlm.nih.gov/pmc/articles/PMC5856726/)

41. Chang C-H, Liu C-Y, Chen S-J, Tsai H-C. Efficacy of light therapy on nonseasonal depression among elderly adults: a systematic review and meta-analysis. Neuropsychiatric Disease and Treatment. 2018; 14: 3091-3102.

(https://www.ncbi.nlm.nih.gov/pmc/articles/PMC6241691/)

42. Sharma MR, Mehta CR, Shukla DJ, Patel KB, Patel MV. Multimodal ayurvedic management for sandhigata vata (osteoarthritis of knee joint). Ayu. 2013; 34(1): 49-55. (https://www.ncbi.nlm.nih.gov/pmc/articles/PMC3764880/)

43. Saxena M. Air quality modelling and non-conventional solutions to environmental problems with reference to vedic science. Thesis for the degree of Doctor of Philosophy (Ph.D.) in Oriental Studies. Haridwar, Uttarakhand, India: Dev Sanskriti Vishwavidyalaya (http://www.dsvv.ac.in); 2006.

44. Bhardwaj A, Sharma MK, Gupta M. Endoscopic evaluation of therapeutic effects of "anuloma-viloma pranayama" in pratishyaya w.s.r. to mucociliary clearance mechanism and Bernoulli's principle. Ayu. 2013; 34(4): 361-367. (https://www.ncbi.nlm.nih.gov/pmc/articles/PMC3968697/)

45. Sinha AN, Deepak D, Gusain VS. Assessment of the effects of pranayama / alternate nostril breathing on the parasympathetic nervous system in young adults. Journal of Clinical and Diagnostic Research. 2013; 7(5): 821-823.

(https://www.ncbi.nlm.nih.gov/pmc/articles/PMC3681046/)

46. Nivethitha L, Mooventhan A, Manjunath NK. Effects of various pranayama on cardiovascular and autonomic variables. Ancient Science of Life. 2016; 36(2): 72-77.

(https://www.ncbi.nlm.nih.gov/pmc/articles/PMC5382821/)

47. Dinesh T, Gaur GS, Sharma VK, Madanmohan T, Kumar KTH, Bhavanani AB. Comparative effect of 12 weeks of slow and fast pranayama training on pulmonary function in young, healthy volunteers: a randomized controlled trial. International Journal of Yoga. 2015; 8(1): 22-26.

(https://www.ncbi.nlm.nih.gov/pmc/articles/PMC4278131/)

48. Banothe GD, Mahanta V, Gupta SK, Dudhamal TS. A clinical evaluation of kanchanara guggulu and bala taila matra basti in the management of mutraghata with special reference to benign prostatic hyperplasia. Ayu. 2018; 39(2): 65-71.

(https://www.ncbi.nlm.nih.gov/pmc/articles/PMC6369605/)

49. Ramachandran AP, Prasad SM, Prasad UN, Jonah S. A comparative study of kaishora guggulu and amrita guggulu in the management of utthana vatarakta. Ayu. 2010; 31(4): 410-416.

(https://www.ncbi.nlm.nih.gov/pmc/articles/PMC3202258/) 